ISSN: $1782-2041$

DOI: $10.25518 / 1782-2041.1284$

\title{
The constitutive function of intentionality in Husserl's phenomenology
}

\author{
NEBOJŠA MUDRI \\ University Hospital Centre Osijek \\ $\triangle$ nebojsa.mudri@kbco.hr
}

\begin{abstract}
The article is addressing one of the central but maybe the most ambiguous and multilayered concepts of Husserl's phenomenology. Husserl's insisting on a form of intentionality that implies not just conscious directedness towards objects, but also a constitutive function of mental acts, led to some serious accusations of his (not only transcendental) idealism and solipsism. Justification of such accusations depends exclusively on whether we understand constitution in an ontological sense, as a creative process which brings worldly entities into being, or in an epistemological sense, as a process which enables us to identify and to interpret a particular givenness as something. In early stages of phenomenology, a so-called "hylomorphic" theory of constitution prevailed, which stated that object of our experience can be present for us only if some sense-data (hyle) is formed in our intentional acts by a meaninggiving component (which Husserl called morphe in his Ideas I). This theory proved to be unsatisfying when Husserl turned to a phenomenological description of temporal objects, discovering that not just objects, but also intentional acts have a distinct temporal structure. However, the analysis of temporal constitution reaches even further, because the idea of the "living present", and its triadic structure of retention-primal impression-protention, holds the key to an explanation of horizon-intentionality, and offers the answer to an essential transcendental question: How is it possible for us to be aware of the world
\end{abstract}


towards which all of our intentional life is directed, and from which all of the motivation for our actions originates?

Keywords Husserl, constitution, intentionality, temporality, world-consciousness.

\section{The subject matter of phenomenology}

In this short paper, I would like to present a general outline of the Husserlian concept of constitution by emphasizing the fundamental role of temporality in constitutive processes belonging to our object-, world-, and self-consciousness. The transcendental unity of Weltbewusstseinsleben will be accordingly disclosed through temporalization. But before we closely examine the core problem of one of the central but maybe most ambiguous and multilayered terms in phenomenology, we must take a few steps back to delineate the horizon from which the concept of constitution emerged in the first place. I will start by trying to resolve some misunderstandings concerning the main task of phenomenology, then I will emphasize the full scope of intentionality in Husserl's thought, and that should gradually take us right into the centre of the constitutive problematic.

It is very hard to find a comprehensive definition of phenomenology which can serve as a straight answer to this simple question: What is the subject matter of phenomenology? What is it all about? If we say that phenomenology is a science concerned with phenomena, nothing much is said. We could get entangled from the very beginning in duplicating entities, arguing that we must distinguish between how things really are and how they only appear to be. Thus, phenomenology, a study of things as they show themselves to us, would be a kind of descriptive enterprise that discloses how people relate to their world in a pre- or non-scientific mode of their being. Although this understanding of phenomenology is utterly wrong, a reference to subjective experience can lead us in a right direction. Yet, Husserl's constant widening of the scope of his investigations leaves numerous phenomenological themes excluded if we think of a subjective experience in common, everyday terms, as something merely subjective or belonging to a particular man, as a sort of unique reaction to the external world comprised of objectively existing things that surround him. Surely, that is not what Husserl had in mind, especially after his philosophical work took a transcendental turn in the first decade of the $20^{\text {th }}$ century. There is a passage from his article written in 1927, which could be 
very helpful in clearing some fundamental misunderstandings related to the subject matter of phenomenology:

Thus there arises the idea of a universal task: Instead of living in "the" world directly in the "natural attitude" and, so to speak, like "children of this world"; that is, instead of living within the latently functioning life of consciousness and thereby having the world, and it alone, as our field of being - as nowexisting for us (from out of perception), as past (from out of memory), as coming in the future (from out of expectation) - instead of judging and valuing this world of experience and making it the field of theoretical or practical projects - instead of all that, we attempt a universal phenomenological reflection on this entire life-process, be it pre-theoretical, theoretical or whatever. We attempt to disclose it systematically and thereby to understand the "how" of its achieving of unities; thus we seek to understand: in what manifold typical forms this life is a "consciousness-of"; how it constitutes synthetically conscious unities; how and in which forms these syntheses, as syntheses of passivity and spontaneous activity, run their course and thereby in particular how their unities are constituted as objectively existing or not existing, and the like; and thus finally how a unified world of experience and knowledge is there, operative and valid for us, in a completely familiar set of ontic types. If it is the case that whatever is experienced, whatever is thought, and whatever is seen as the truth are given and are possible only within [the corresponding acts of] experiencing, thinking, and insight, then the concrete and complete exploration of the world that exists and has scientific and evidential validity for us requires also the universal phenomenological exploration of the multiplicities of consciousness in whose synthetic changes the world subjectively takes shape as valid for us and perhaps as given with insight (Encyclopedia Britannica article, Draft A). ${ }^{1}$

So, when we say that phenomenology analyses experience, this means it is concerned with worldly objects onto which we are directed in our conscious life, primarily in the scope of how they appear or show themselves to us. Appearing, on the other hand, has a threefold structure: something appears in a certain way to someone, and that "certain way" is determined by a complex of intentional acts which present us with the object we are conscious of. "I see a tree", means that the tree is here for me as seen. Later on maybe, when it ceases to be "bodily-present", I can have a recollection of the same tree but then it

${ }^{1}$ Edmund Husserl, Psychological and Transcendental Phenomenology and the Confrontation with Heidegger (1927-1931), translated by Thomas Sheehan and Richard E. Palmer (Dordrecht: Kluwer Academic Publishers, 1995), p. 87. 
would appear to me as remembered. So, the "consciousness-of" has an essentially threefold structure: ego-cogito-cogitatum. ${ }^{1}$ The cogito, or mental act, is the link that secures the content of my consciousness, and makes it possible for this content to be a part of a unified stream of thought that I can rightly call mine. Husserl speaks of the two poles of intentional relation: the I-pole and the object-pole. But the main "catch" here is to abstain from thinking of these two poles as two separate entities that come in a kind of external, casual or coincidental relation to one another. In a strict sense, neither the pure transcendental ego nor the constituted experienced object, are entities that can exist per se. Without objectifying acts there are no objects, and without constitutive activity, there is no subjectivity. ${ }^{2}$

But now we came to extreme conclusions too fast. We must slow our pace a bit and examine the main characteristics of Husserl's concept of intentionality. Without a doubt, intentionality is the sun in the phenomenological universe. Every other occurring problem somehow revolves around it, so a proper understanding of this essential property of our consciousness should cast light on the otherwise obscure foundation of our knowledge that must bridge the artificial gap between minds and the world. In section 146 of the first book of his famous Ideas Pertaining to a Pure Phenomenology and to a Phenomenological Philosophy (1913), Husserl had stated that intentionality is the name of the problem encompassed by the whole of phenomenology. This must be understood very seriously. But if we think of intentionality as a mere directedness or "aboutness" of mental states, it is hard to see how a wide-range philosophical project such as phenomenology could have been built upon it.

\section{Husserl's confrontation with Brentano and development of a compre- hensive concept of intentionality}

In pursuing a closer determination of intentionality, Husserl began to follow his teacher Franz Brentano, an Austrian philosopher whose lectures Husserl attended in Vienna in the 1880s. But if we take a closer look, we will see that

\footnotetext{
${ }^{1}$ Edmund Husserl, Cartesian Meditations. An Introduction to Phenomenology, translated by Dorion Cairns (The Hague: Martinus Nijhoff Publishers, 1960), p. 31-33. Edmund Husserl, The Paris Lectures, translated by Peter Koestenbaum (Dordrecht: Kluwer Academic Publishers, 1967), p. 12-14.

${ }^{2}$ Husserl is, therefore, operating with two concepts of subjectivity: abstract and empty I-pole, and concrete "life of worldly consciousness". See Dan Zahavi, Husserl und die transzendentale Intersubjektivität. Eine Antwort auf die sprachpragmatische Kritik (Dordrecht: Kluwer Academic Publishers, 1996), p. 188-199.
} 
Husserl radically changed and deepened Brentano's concept. A very frequently cited passage from Brentano's major work Psychology from an Empirical Standpoint states:

Every mental phenomenon is characterized by what the Scholastics of the Middle Ages called the intentional (or mental) inexistence of an object, and what we might call, though not wholly unambiguously, reference to content, a direction toward an object, or immanent objectivity. Every mental phenomenon includes something as an object within itself, although they do not all do so in the same way. In presentation something is presented, in judgment something is affirmed or denied, in love loved, in hate hated, in desire desired and so on. ${ }^{1}$

There are at least two problematic assumptions in Brentano's view from that period: 1) intentionality is a characteristic of every mental phenomenon; 2) intentional objects have only inner existence (or inexistence) in the acts of thinking. Regarding the first assumption, Husserl rightfully says:

It can be shown that not all "psychical phenomena" in the sense of a possible definition of psychology, are mental acts in Brentano's sense, and that, on the other hand, many genuine "psychical phenomena" fall under Brentano's ambiguous rubric of "physical phenomena". ${ }^{2}$

Headache is not directed towards the head, nor is it about the head, and certainly it cannot be said that the head exists in the act of headache. With the other counterexamples, such as anxiety, depression, joy and astonishment, the situation is far more complex. Here the particular object of a mental state we found ourselves into cannot be easily determined. Stricken with those kinds of moods, the subject faces nothingness, his whole life, or the totality of the surrounding beings. By calling them "fundamental attunements", Heidegger tried to show that phenomena such as anxiety, profound boredom, and astonishment are not thematic or object-directed, rather they are disclosing Dasein's beingin-the-world. ${ }^{3}$ But what about the simpler contents of our consciousness, such

${ }^{1}$ Franz Brentano, Psychology from an Empirical Standpoint, translated by Linda L. McAlister (New York and London: Routledge, 1995), p. 68.

${ }^{2}$ Edmund Husserl, Logical Investigations, translated by John Niemeyer Findlay (New York and London: Routledge, 2001), p. 94.

${ }^{3}$ Insightful discussion on that matter, revealing its wide range of implications, is presented in: Michel Haar, "Attunement and Thinking", in Heidegger Reexamined (Volume 3): Art, Poetry and Technology, eds. Hubert Dreyfus and Mark Wrathall (New York and London: Routledge, 2002), p. 149-162. 
as the sensations of color, pleasure, or warmth. They are, of course, mental phenomena, but are they intentional? According to Husserl, the answer is negative:

A real being deprived of such experiences (and thus a mere complex of sensations) merely having contents inside it such as the experiences of sensation would be unable to interpret these objectively, or otherwise use them to make objects present to itself, quite incapable, therefore, of referring to objects in further acts of judgment, joy, grief, love, hatred, desire and loathing — such a being would not be called 'psychical' by anyone. ${ }^{1}$

So, the sensuous content needs to be objectively interpreted - intention enables us to experience something as an object of a certain kind. This is one of the four main characteristics of intentionality, already recognized by one of the first historians of the phenomenological movement, Herbert Spiegelberg. A closer look at these characteristics will finally throw us right into the labyrinth called a constitutive function of intentionality. According to Spiegelberg, ${ }^{2}$ intention objectifies, identifies, connects and constitutes.

Firstly, it could be said that intention "interprets" pre-given sensuous materials as something, so the complete or whole object is present for us. In other words, it refers to the data (Empfindungsdaten) which are integral (reell) parts of the stream of consciousness as "intentional objects". It is a function of intention to relate these data to an object which itself is not part of the act, but "transcendent" to it. Here we already see that Brentano's second problematic assumption - the intentional inexistence of objects of thought ${ }^{3}$ - is abandoned by Husserl. The phenomenological rejection of all immanence-theories is clearly stated in the last of Husserl's lectures from 1907, posthumously published under the title The Idea of Phenomenology, but it can also be found already in Logical Investigations:

[T] he objects of which we are "conscious", are not simply in consciousness as in a box, so that they can merely be found in it and snatched at in it; (...) they

\footnotetext{
${ }^{1}$ Edmund Husserl, Logical Investigations, p. 94-95.

${ }^{2}$ Herbert Spiegelberg, Phenomenological Movement: A Historical Introduction (Dordrecht: Kluwer Academic Publishers, 1960), p. 108-110.

3 Detailed analysis of Brentano's concept of intentionality can be found in: Tim Crane, "Brentano's Concept of Intentional Inexistence", in Austrian Contribution to Philosophy, ed. M. Textor (London: Routledge, 2006), p. 20-35.
} 
are first constituted as being, what they are for us, and as what they count as for us, in varying forms of objective intention. ${ }^{1}$

Apart from its objectifying function, intention identifies objects, it assigns a variety of successive data to the same referents or poles of meaning (noema). As Spiegelberg puts it: "Intention supplies the synthetic function by which the various aspects, perspectives and stages of an object are all focused upon, and integrated into, identical core". ${ }^{2}$

Another very important feature of intention is that it connects related aspects and the surrounding background of an identical object which forms its horizon. Husserl developed his concept of horizon ${ }^{3}$ under the strong influence of William James' fringe-theory. According to James, it is possible to distinguish two parts of our awareness, one is definite and the other vague - the nucleus and the surrounding fringe. The fringe represents the context and the web of relations that define the meaning of the nucleus. ${ }^{4}$ Husserl's analyses showed that with every present object there is an implicitly co-present background that determines our experience of the object and enables us to move forward from what is currently given. In his late text Experience and Judgment, Husserl speaks of the inner and the outer horizon. Our deepening of the former would signify the further detailed determination of the same object, and our expanding of the latter means further referring to the other objects and connected thematic fields.

Because our conscious acts are essentially "horizonal", they always include present as well as absent parts of their objects which constitute their full meaning. ${ }^{5}$ I see the table before me and not just one side of it. But that does

${ }^{1}$ Edmund Husserl, Logical Investigations, p. 275.

${ }^{2}$ Herbert Spiegelberg, Phenomenological Movement: A Historical Introduction, p. 109.

${ }^{3}$ The only extensive and systematic inquiry into horizon-problematic in Husserl's phenomenology is offered in: Saulius Geniusas, The Origins of the Horizon in Husserl's Phenomenology (Dordrecht: Springer, 2012).

${ }^{4}$ William James, The Principles of Psychology (New York: Henry Holt and Company, 1890), p. 258-259.

${ }^{5}$ See the following passage: "The objective sense, however, is not merely a collection of what is intuited and what is not intuited. For what is given is itself permeated by absence, by what is not given [...] As what is identical throughout a family of perceptual phases, the objective sense is also the difference between what is given and what is absent" (Donn Welton, "Structure and genesis in Husserl's phenomenology", in Ed- 
not mean that I am concluding anything about the non-given aspects. That would involve engaging in a further act of judgment. Presence and absence are instantly here for me. Surely, not in the same way, but I am intending the whole object and not just one of its aspects. However, this "instance" does not mean a punctual "now", but it refers to a living present which opens up a horizon for every possible encounter with beings. We'll get to that later, in our analysis of temporal constitution. But there are also at least two other possible answers to the question of how it is possible for intention to step beyond immediately given and direct the ego onto the full object and not just some current representation of it. This curious intentional instantaneous "movement" from present to absent aspects of an object could be explained from the standpoint of phenomenology of embodiment and kinesthetic sensations. Husserl tried to elucidate these phenomena by referring to the acts of visual perception. Although only one side of an object situated in my perceptual field is appearing before my eyes, I see the whole object because my perceptive act objectifies its data. This "objectivation" rests upon the fundamental "I can" of further determination. I can go around the object and see its currently hidden sides and its rear. This "I can" is founded upon our kinesthetic bodily experiences and already mentioned fringes that motivate our further intentional movement. We are essentially embodied subjects, and our embodiment includes the possibility to move our sensory organs. Although I cannot see the rear of a given object at this moment, when I am frontally directed towards the object I am also aware of its rear. Consequently, absence for Husserl is not nothingness - absence means real (not just logical) possibility for being present.

Furthermore, a transcendental fact of foreign subjectivity (alter-ego) necessary leads me to a similar experience. I see you looking at the same table as me but from the other side of the room. What is hidden from me is clearly there for you. Your experience of the object is, surely, only indirectly present for me, but my empathic appresentation enables me to see more than I actually see, because I am, so to speak, also looking through your eyes. So, I'm constantly aware that I'm not surrounded only with spatiotemporal things but with other co-constituting subjects who are responsible for the meaning of the objective world and the scientific third-person perspective. The objective world is constituted by transcendental intersubjectivity, and Husserl tried to give a proper phenomenological justification for this position not only in the Fifth Meditation, but in his almost entire philosophical lifetime.

mund Husserl. The Web of Meaning: Language, Noema, and Subjectivity and Intersubjectivity, eds. Rudolf Bernet, Donn Welton, and Gina Zavota (Routledge: London and New York, 2005), p. 243-244). 
Finally, we come to the fourth, constitutive function of intentionality. This one is the most problematic because when Husserl says that every object is the "achievement" (die Leistung) of an intentional act, it is very easy to misconceive this relation in a sense of creative or causal process. But neither are objects made in the intentional acts nor is subjectivity the effective cause of things onto which it directs itself. However, in section 33 of Ideas Husserl says that the world has only a relative being, in contrast to the transcendental ego which discloses itself after the reduction as a phenomenological residuum, whose being is absolute. This should not be understood in a general metaphysical sense, as a statement about the modes of existence of beings, some of which are of higher ontological order than others. Everything experienced depends on the very possibility of experience; appearing implies that something appears to someone and it is thus relative to the one it appears to, but this does not have anything to do with a thesis according to which everything that exists owes its existence to some absolute entity. Constitution is an epistemic rather than ontological relation. "I constitute the object of my experience" means that in my experiencing I am determining the other intentional pole as an object of a certain kind and with certain features, and I am placing it somewhere in the network of my knowledge about the world.

\footnotetext{
${ }^{1}$ This directly contradicts Ingarden's claim that transcendental phenomenology is in its essence a metaphysical idealism: "The material things given in perception and thought in the cognitive acts superstructured over perception are not an autonomous (separate in relation to conscious experiences) sphere of autonomous being in itself; they are only something that exists in its essence "for" the conscious subject performing the perceptive acts. They are only intentional units of sense and beyond that ein Nichts" (Roman Ingarden, On the Motives Which Led Husserl to Transcendental Idealism [The Hague: Martinus Nijhoff 1975], p. 32-33). Phenomenology is, in my opinion, metaphysically indifferent philosophy, neither metaphysical idealism nor realism, because the question of what is per se, i.e. beyond consciousness, falls outside the scope of both descriptive and explanatory analytics of intentional acts (see Edmund Husserl, Cartesian Meditations. An Introduction to Phenomenology, p. 139: "Our monadological results are metaphysical, if it be true that ultimate cognitions of being should be called metaphysical. On the other hand, what we have here is anything but metaphysics in the customary sense...").
} 


\section{Hylomorphic constitution}

In Husserl's case, it is immediately possible to differentiate between two layers of constitutive processes: the hylomorphic constitution and the temporal constitution. But a more careful examination of his later analyses of time consciousness, done in collaboration with his last assistant Eugen Fink, leads to the conclusion that temporal constitution is not just about temporal objects, for instance, melody, or even about the constitution of intentional acts which are all part of a unified stream of consciousness, but, as Fink writes in one of his manuscripts, the constitution of time is ultimately the constitution of the universal horizon, i.e. primordial temporalization is the constitution of the world. We said earlier that the intentional process necessary includes two poles, the I-pole and the object-pole. However, in transcendental attitude, intentionality in its main function serves as a constitution of the horizon for every possible appearing, and thus phenomenological reflection discovers transcendental intersubjectivity and the world acting as two intentional poles. But in the case of transcendental constitution, these poles are even more closely related, so much so that Husserl speaks of Weltbewusstseinsleben. This primal structure should be understood as the foundation for every kind of intentionality.

Earlier we talked about the objectifying function of intention and we mentioned Husserl's critique of Brentano's concept of immanent existence of objects in mental acts. The very fact that we can relate a variety of data to the same object, and do so in various intentional acts, proves that an object is not inexistent but transcendent to the mental act. When I am in fear of a poisonous snake, the horrifying object is transcendent to my fear, for I relate its visual appearance, the particular movements I am noticing, the hissing and other successive sensuous contents to the snake I am in fear of, which in turn appears to me as something horrifying in an intentional act of fear. In Logical Investigations, Husserl distinguished between the psychical, immanent (reell) content of the act and the transcendent correlate of the act. This immanent content was made up of two different components, the sensations (Empfindungsdaten) and the concrete intentions qua psychical processes.

In Ideas I, Husserl continues to hold this position, but puts it by means of a new, Aristotelian terminology. According to Ideas, the stream of consciousness contains two different components: the first one is a level of nonintentional sensuous content, be it visual, auditory or olfactory sensations, sensations of pain, itching, and so forth. Husserl speaks of sensuous matter (hyle) or simply of hyletic matter. The second one is an intentional dimension of animating or meaning-giving components. Husserl calls them intentional forms 
(morphe), but he also, and more frequently, speaks of noesis or noetic component. ${ }^{1}$ Maybe it would be easier to understand this division by drawing an analogy with mathematical functions: a set of input variables (in this case the sense-data) cannot produce any output if they are not related or ordered in a certain way; this formula or algorithm (in our case, an intentional morphe) defines how to compute the output from a given input. Sense-data could not be directed towards an object by themselves. So, Husserl did not hold that we have raw sensations as independent acts on which the acts of perception are based - sensory matter and intentional form are moments of the same mental act. Whereas both components are immanent to the act, the transcendent, constituted correlate is now called noema. Already from his terminological choices, it should be clear that Husserl analyses the constitution of meaning, not the creation of physical entities. Fearsome poisonous snake does not exist because I intended it. Rather, I constitute it as horrifying because it appears to me that way in a series of complex intentional acts (my fear is based on some visual data, background beliefs, unpleasant past experiences and so on). It should be noted, however, that the level of constitutive creativity rises with our intentional distancing from raw sensual content. In constituting, for example, some state of affairs the ego is fully involved, using its predicative power and thus forming a "categorical object". The example of categorical objects is recognized by some Husserl-scholars ${ }^{2}$ as very untypical, because it is the only case where constitution actually produces or construes its object. So, it is not only the meaning but the very existence of categorical objects that depends on the acts directed at them.

\section{Temporal constitution}

The traces of his hylomorphic concept of constitution can already be found in Husserl's early texts, but when he started to think about a familiar phenomenon - the intentional directedness towards other intentional acts (when you, for example, remember your jealousy towards your husband's secretary) - Husserl discovered the constitutive significance of temporal structure common to both temporal objects and acts which intend them. But that implies more than

\footnotetext{
${ }^{1}$ Edmund Husserl, Ideen zu einer reinen Phänomenologie und phänomenologischen Philosophie. Husserliana III. (The Hague: Martinus Nijhoff Publishers, 1950), p. 192196.

${ }^{2}$ See Wolfgang Huemer, The Constitution of Consciousness: A Study in Analytic Phenomenology (New York: Routledge, 2005), p. 17-18.
} 
just the fact that objects are extended in time in the same way as intentional acts. Husserl did not suddenly change the way he was using the term "constitution". He did not start to speak about "a way in which a thing is constituted, established, made or ordered", instead of "an act of establishing, ordering or settling". In that case, temporality would be something like a common essential property of intentional acts and objects changing in time. But Husserl, as well as Kant before him (in his short but extremely significant description of transcendental schematism), ${ }^{1}$ understood constitution primarily as temporalization (Zeitigung). ${ }^{2}$ Objects of our experience, as well as our intentional acts, are in succession (following one another), they have a certain duration, and also a possibility to appear simultaneously. But on a fundamental level, experiential time is constituted in the stream of consciousness as a horizon which enables intentional movements of the ego, thus opened for the world from which objects can appear to it. Consequently, we can find three levels of constitution in Husserl's account of time-consciousness: "(1) the things of experience in objective time [...] (2) the constituting appearance manifolds of various levels, the immanent units in pre-empirical time; (3) the absolute, timeconstituting stream of consciousness". ${ }^{3}$

\footnotetext{
${ }^{1}$ Immanuel Kant, Critique of Pure Reason, translated by Friedrich Max Müller (London: Macmillan, 1922), p. 112-120.

${ }^{2}$ According to Sandmayer, Husserl's motivation to seriously engage in researching the constitutive function of inner time-consciousness came from mentoring Roman Ingarden's dissertation on Henri Bergson's philosophy. Husserl and Ingarden devoted special attention to Bergson's distinction between la durée pure and le temps, with additional efforts to better understand the nature of sense-data, which led to the breakthrough to a genetic phenomenology in Husserl's later Bernau investigations. See Bob Sandmayer, Husserl's Constitutive Phenomenology. Its Problem and Promise (London and New York: Routledge, 2008), p. 88. Nevertheless, one should pay attention to the fact that Husserl started to hold seminars on Kant's theoretical philosophy (especially concerning themes elaborated in Prolegomena and Kritik der reinen Vernunft) as early as winter semester of $1897 / 1898$. Husserl gave the last one, under the title Phenomenological Exercises (on Kant) for Advanced Students, at the University of Freiburg in the summer semester of 1927, so we can freely conclude that Kant's transcendental idealism (including his emphasis put on the crucial role of schematic temporalization as the connective tissue between categories and intuitions) was his lifelong inspiration, although he distanced phenomenology far from the obscure concept of a thing-in-itself.

${ }^{3}$ Edmund Husserl, On the Phenomenology of the Consciousness of Internal Time (1883-1917), translated by John Barnett Borough (Dordrecht: Kluwer Academic Publishers, 1991), p. 77.
} 
Every intentional act has a tripartite temporal structure. Husserl calls "primal impression" what is immediately, or just now, present to consciousness. But this narrowly directed intentional grasp of the "now" of whatever is being experienced at that moment never happens in isolation. There are two further structural aspects: the part of the act which is directed towards an object as it appeared just a moment ago, a just-elapsed phase of the enduring object, terminologically referred to as "retention", and the more or less indefinite anticipation of the immediately future state of the object — or, as Husserl calls it, the "protention". Together they form a living present (lebendige Gegenwart) - an intermediate dimension between presence and absence. Primal impression discloses what is actually present or given in fullness, but the primal impression is only a partial intention, for the whole intentional act also requires retentional and protentional parts. Retentions and protentions, on the other hand, are neither fully present nor totally absent, but they are parts of the same intentional act as a primal impression. Retention is not to be confused with the act of remembering something about the object's past states, nor is protention a kind of expectation because this would imply employing another intentional act, which is not the case here. When I hear a melody, I am not, so to speak, going out of auditive perception with every new tone appearing in succession to recollect about the one I heard just a moment ago. Retention holds the constituted parts of the temporal object - parts which sediment one beneath the other, fading more and more without fully disappearing. Constitution leaves a kind of trace, and as a rule, when some object is constituted very often, our consciousness forms a habit that shapes future constitutions.

Consciousness is dynamic in a twofold sense: it is intentionally engaged with objects in the continuous manifold of their appearing, and it is structuring the continuity itself as continuity (continuity both of that object-manifold appearing in it and of its own perdurance). So, temporality is the experienced time of the appearing object-manifold, but also the primordial constituting action which enables a unified stream of consciousness. ${ }^{1}$ To explain this phenomenon, Husserl employs a distinction between transversal and longitudinal intentionality, solving the problem of objective as well as subjective synthesis

\footnotetext{
${ }^{1}$ Landgrebe is following Fink in emphasizing the ambiguity of Husserl's understanding of constitution (not just as Sinnbildung but also as Kreation) on the level of primary passive synthesis. Primary passivity refers to the syntheses of time-consciousness in which the ego (transcendental life) constitutes itself as temporal flow and becomes aware of itself as a unified stream of consciousness. See Ludwig Landgrebe, "Reflexionen zu Husserl's Konstitutionslehre", Tijdschrift voor Filosofie 3 (1974), p. 466482.
} 
at one stroke. Retention keeps available to current experience the intentional sense of an object that just slipped into the past, but also retains the just-elapsed phase of experience itself. The same is true about protentions: I am not just anticipating that something more is about to happen (however indeterminate it may be), but I am also anticipating my experience of what is about to happen. To quote Gallagher: "My experience of the passing or enduring object (transverse intentionality addressing objective synthesis) is at the same time a nonobservational, pre-reflective awareness of my own flowing experience (longitudinal intentionality addressing subjective synthesis)". ${ }^{1}$

Singular unified stream of consciousness is, therefore, also temporally conditioned, and not just objects which an I-monad intentionally constitutes. But what about the intersubjective relation of empathy we spoke of earlier? Empathizing stream and empathized stream cannot belong to the same phenomenological I, but they "belong to the same time [...]. Empathy posits the empathized as now and posit it in the same now as it, itself'. ${ }^{2}$ Foreign subjectivity is "appresented" to me through his or her body and bodily behaviour. The body of an alter-ego needs to be recognized as a lived body (Leib), that is, as a sensing, spatially oriented, autonomously moving bearer of kinaesthetic experience. This animate organism shows "harmonious behaviour", coherence and continuity of gestures and movements "from phase to phase". In synchronizing with the other we are getting attuned with this temporal structure, interacting and cooperating in the "shared" present (as well as in the same context of things and commonplace, in the surrounding world), thereby mutually constituting "we-together" intentionality. ${ }^{3}$ So, although we cannot experience the other's stream of consciousness, we can apprehend it through empathy because my own streaming present "coincides" with that of the other.

We designated earlier the unified structure of retention-primal impression-protention as an intermediate dimension which grounds all appearing and disappearing. The proper name for this ground is world-consciousness. As Fink rightly emphasizes in one of his manuscripts from his assistant years (when he was in close collaboration with Husserl), the constitution of time is

${ }^{1}$ Shaun Gallagher, "Husserl and the Phenomenology of Temporality", in H. Dyke, H. and A. Bardon (eds.), A Companion to the Philosophy of Time (Oxford and Malden: Wiley-Blackwell, 2013), p. 140-141.

${ }^{2}$ Edmund Husserl, The Basic Problems of Phenomenology. From the Lectures, Winter Semester 1910-1911, translated by Ingo Farin and James G. Hart (Dordrecht: Springer, 2006), p. 85.

${ }^{3}$ Marek Pokropski, "Timing together, acting together. Phenomenology of intersubjective temporality and social cognition", Phenomenology and Cognitive Sciences 14 (2015), p. 904. 
not the constitution of object, but the constitution of the universal horizon. The consciousness of the world, the awareness of all-embracing horizonality, has to be a "non-thematic consciousness", not an object-oriented act of interpreting the intuitively given. Fink uses the metaphor of "swinging" (Manuscript Z-V III) ${ }^{1}$ to depict the internal movement of partial intentions and the opening of horizon for every possible encounter with inner-worldly beings. Fink surely gained the impetus for his descriptions of temporal conditioning of world-consciousness, not only from Husserl's unpublished writings and conversations, but also from Heidegger's lectures which addressed ecstatic temporality of Dasein. Our being-towards-death is ecstatic in the sense that the Dasein projects itself towards its own possibilities, and ultimately towards its possibility of non-possibility - the existential meaning of death - a kind of "unsurpassable wall" from which our projecting bounces back towards its alreadyness, thus opening the $D a$ of Dasein. As Heidegger puts it, "death, as the possibility of Da-sein we characterized, throws anticipatory existence back upon its factical throwness". 2 This movement, which unifies schemata of future, present and having-been, delineates the world-horizon. To quote Heidegger again: "On the basis of the horizonal constitution of the ecstatic unity of temporality, something like a disclosed world belongs to the being that is always its There". ${ }^{3}$ Heidegger, of course, speaks about an ontological dimension which he founds to be more fundamental than our conscious intentional life, be it mundane or transcendental. But like Husserl and Fink, he also realizes that our openness for the world is temporally conditioned.

\section{Conclusion}

I would like to conclude my presentation by admitting that up to this point we have only scratched the surface of an extremely complex set of philosophical problems related to a phenomenological concept of constitutive intentionality. ${ }^{4}$

\footnotetext{
${ }^{1}$ Roland Bruzina, Edmund Husserl and Eugen Fink: Beginnings and Ends in Phenomenology 1928-1938 (New Haven and London: Yale University Press, 2004), p. 252.

${ }^{2}$ Martin Heidegger, Being and Time, translated by Joan Stambaugh (Albany: State University of New York Press, 1996), p. 353.

${ }^{3}$ Ibid., p. 334.

${ }^{4}$ The intersection of analyses concerning time-consciousness and our constitutive being-in-the-world represents the culmination of efforts done by members of the Phänomenologische Werkstatt, namely Husserl and his assistants. This was a relatively short but intense period of their co-thinking, as well as counter-arguing, in search for the meaningful grounds of knowledge and everyday life. So, when we try
}

15

Bull. anal. phén. XVII 8 (2021)

https://popups.uliege.be/1782-2041/ @ 2021 ULiège BAP 
My rudimentary description of the principles of object- and horizon-constitution through the hylomorphic and temporal models has left out vast concrete analyses Husserl carried out primarily in the second book of his Ideas, as well as in Cartesian Meditations, and the whole range of manuscripts dealing with the constitution of spatiotemporal nature, body, others, objective and cultural world, values, time, etc. So, the addressed constitution of perceptual objects and the constitution of the world as the universal horizon of our experiences represent two extreme sides of a highly diversified process of object-, horizonand self-constitution of transcendental consciousness. But these extreme sides already show that the crucial role in this process may be imputed to temporalization.

The question, however, arises as to whether the temporal constitution is to be understood as a fundamental constitutive layer of passive synthesis which can "co-exist" with the hylomorphic constitution at the level of active thematizations, ${ }^{1}$ or whether, on the other hand, Husserl finally abandoned the structural model of constitution in favor of genetic phenomenology. According to the second interpretation, the hylomorphic model of constitution is ultimately unsatisfying $^{2}$ and has to be replaced with the temporal model. Genetic phenomenology "destroys" the matter-form dichotomy because both elements are "constituted by a manifold of temporal phases emanating from the immediate present". ${ }^{3}$ This flow of primal intentions is what the late Husserl simply refers to as "life". So, his odd syntagma Weltbewusstseinsleben refers to the primal intentionality of which (inter)subjectivity and the world are two interrelated poles. Together they form a transcendental condition for every possible experiencing. This is, again, a non-metaphysical claim, but also a claim which is not solely epistemological, because Erlebnis covers everything we can encounter in all modifications of our conscious life.

It seems to me that there is one additional of relating hylomorphic and temporal constitutive intentionality, which rests on a closer reading of Aristotle's Physics (A 189b17-192b5). In using the notions of hyletic matter and intentional form in his early static analyses, Husserl leaves privation (steresis)

to elucidate the phenomenological concept of constitutive intentionality, we should exclusively address Husserlian transcendental philosophy, no matter what else goes by the name of phenomenology.

${ }^{1}$ Bob Sandmayer, Husserl's Constitutive Phenomenology. Its Problem and Promise, p. 85.

${ }^{2}$ Matter-form schema is unsatisfying because it cannot explain the constitution of intentions, the constitution of sensations, and the constitution of objective time.

3 Robert Sokolowski, The Formation of Husserl's Concept of Constitution (The Hague: Martinus Nijhoff Publishers, 1970), p. 205. 
- the third element which is necessary to explain the possibility of change in natural beings - out of the picture. For every natural process begins with the possibility for the matter to gain some shape or form. This possibility is a lack or absence of determination (incidental privation), which becomes realized at the end of the formative process. ${ }^{1}$ The notion of steresis already opens the temporal horizon in hylomorphic constitution understood as mental processing of sense-data. Husserl is apparently not aware of that, neither are contemporary cognitive neuroscientists who are using the terms 'differentiation' or 'informativeness' to describe an essential feature of consciousness, namely: the fact that every time we experience something, our experience results from the reduction of uncertainty among a vast number of alternative mental states, which reflects the discriminatory capability of consciousness. ${ }^{2}$ There is also an inherent mechanism of filtering the incoming signals, on the level of passive syntheses, that depends not only on the length and strength of the stimulus but on perceptual predictions, where we consciously perceive what is coherent with previous experiences and in the context of what we ambiguously expect in the next moment, ${ }^{3}$ i.e., on the basis of the triadic structure of the living present.

By touching on the problem of the constitutive function of intentionality, we have reached the hardest, abysmal and aporetic problem, not only of phenomenological, but of philosophical research in general. Our thinking always fails in its attempt to somehow transcend or distance itself from time in such a way that it could be delineated and grasped as a research subject in a satisfactory manner. However, time, as a pure embracement and containment of everything as well as the unique kind of self-withdrawal from it, continuously challenges philosophical investigation. Maybe the solution to the issue of time would secure the final point of rest to the thinking beings, but the unrestful nature of time keeps philosophy in the constant movement of questioning and, thus, renewal through a reconceptualization of itself.

\footnotetext{
${ }^{1}$ Aristotle, Physics (Lincoln: University of Nebraska Press, 1961), p. 18-19.

2 See Giulio Tononi, "Consciousness, information integration, and the brain", Progress in Brain Research 150 (2005), p. 109-126; Anil Seth, Izhikevich, E., Reeke, G. N. \& Edelman, G. M., "Theories and measures of consciousness: An extended framework", Proceedings of the National Academy of Sciences of the United States of America 103 (2006), p. 10799-10804.

${ }^{3}$ See Anil Seth, “The real problem", Aeon, 02.11.2016. (https://aeon.co/essays/thehard-problem-of-consciousness-is-a-distraction-from-the-real-one).
} 


\section{References}

Aristotle. Physics. Translated by Richard Hope. Lincoln: University of Nebraska Press, 1961.

Brentano, Franz. Psychology from an Empirical Standpoint. Translated by Linda L. McAlister. London and New York: Routledge, 1995.

Bruzina, Ronald. Edmund Husserl and Eugen Fink: Beginnings and Ends in Phenomenology 1928-1938. New Haven and London: Yale University Press, 2004.

Crane, Tim. "Brentano's Concept of Intentional Inexistence". In Austrian Contribution to Philosophy, edited by Mark Textor, 20-35. London and New York: Routledge, 2006.

Gallagher, Shaun. "Husserl and the Phenomenology of Temporality". In A Companion to the Philosophy of Time, edited by Heather Dyke and Adrian Bardon, 135-150. Oxford and Malden: Wiley-Blackwell, 2013.

Geniusas, Saulius. The Origins of the Horizon in Husserl's Phenomenology. Dordrecht: Springer, 2012.

Haar, Michael. "Attunement and Thinking”. In Heidegger Reexamined (Volume 3): Art, Poetry and Technology, edited by Hubert L. Dreyfus and Mark A. Wrathall, 149-162. London and New York: Routledge, 2002.

Heidegger, Martin. Being and Time. Translated by Joan Stambaugh. Albany: State University of New York Press, 1996.

Huemer, Wolfgang. The Constitution of Consciousness: A Study in Analytic Phenomenology. London and New York: Routledge, 2005.

Husserl, Edmund. Ideen zu einer reinen Phänomenologie und phänomenologischen Philosophie. Husserliana III. The Hague: Martinus Nijhoff, 1950.

- Cartesian Meditations. An Introduction to Phenomenology. Translated by Dorion Cairns. The Hague: Martinus Nijhoff, 1960.

- The Paris Lectures. Translated by Peter Koestenbaum. Dordrecht: Kluwer Academic Publishers, 1967.

- On the Phenomenology of the Consciousness of Internal Time (1883-1917). Translated by John Barnett Borough. Dordrecht: Kluwer Academic Publishers, 1991.

-. Psychological and Transcendental Phenomenology and the Confrontation with Heidegger (1927-1931). Translated by Thomas Sheehan and Richard E. Palmer. Dordrecht: Kluwer Academic Publishers, 1995.

- Logical Investigations. Translated by John N. Findlay. London and New York. Routledge, 2001.

- The Basic Problems of Phenomenology. From the Lectures, Winter Semester 1910 1911. Translated by Ingo Farin and James G. Hart. Dordrecht: Springer, 2006.

- The Idea of Phenomenology. Translated by Lee Hardy. Dordrecht: Kluwer Academic Publishers, 2010.

Ingarden, Roman. On the Motives Which Led Husserl to Transcendental Idealism. The Hague: Martinus Nijhoff, 1975.

James, William. The Principles of Psychology. Volume I. New York: Henry Holt and Company, 1890. 
Kant, Immanuel. Critique of Pure Reason. Translated by Friedrich Max Müller. London: Macmillan, 1922.

Landgrebe, Ludwig. "Reflexionen zu Husserl's Konstitutionslehre". Tijdschrift voor Filosofie 3 (1974): 466-482.

Pokropski, Marek. "Timing together, acting together. Phenomenology of intersubjective temporality and social cognition". Phenomenology and Cognitive Sciences 14 (2015): 897-909.

Sandmayer, Bob. Husserl's Constitutive Phenomenology. Its Problem and Promise. London and New York: Routledge, 2008.

Seth, Anil. "The real problem". Aeon, 02.11.2016. (https://aeon.co/essays/the-hardproblem-of-consciousness-is-a-distraction-from-the-real-one).

Seth, Anil, Eugene Izhikevich, George N. Reeke, and Gerald E. Edelman. "Theories and measures of consciousness. An extended framework". Proceedings of the $\mathrm{Na}$ tional Academy of Sciences of the United States of America 103 (2006): 10799. 10804.

Sokolowski, Robert. The Formation of Husserl's Concept of Constitution. The Hague: Martinus Nijhoff, 1970.

Spiegelberg, Herbert. Phenomenological Movement. A Historical Introduction. Dordrecht: Kluwer Academic Publishers, 1960.

Tononi, Giulio. "Consciousness, information integration, and the brain". Progress in Brain Research 150 (2005): 109-126.

Welton, Donn. "Structure and genesis in Husserl's phenomenology". In Edmund Husserl. The Web of Meaning: Language, Noema, and Subjectivity and Intersubjectivity, edited by Rudolf Bernet, Donn Welton, and Gina Zavota, 238-260. London and New York: Routledge, 2005.

Zahavi, Dan. Husserl und Die Transcendentale Intersubjektivität. Eine Antwort auf die sprachpragmatische Kritik. Dordrecht: Kluwer Academic Publishers, 1996. 